ISSN : 2303-1514 | E-ISSN : 2598-5949

\title{
DEVELOPING TRILINGUAL SMART BOOK MEDIA AS A LITERACY FACILITY FOR THIRD GRADE STUDENTS OF ELEMENTARY SCHOOL
}

\author{
Rita Umyati ${ }^{1}$, Rina Yuliana ${ }^{2}$, Odien Rosidin ${ }^{3}$ \\ ${ }^{1,2,3}$ Program Studi Pendidikan Guru Sekolah Dasar, FKIP Universitas Sultan Ageng Tirtayasa, Indonesia \\ ritaumyati@gmail.com, rinayuliana@untirta.ac.id, odienrosidin@untirta.ac.id

\section{PENGEMBANGAN MEDIA BUKU PINTAR TRILINGUAL SEBAGAI SARANA LITERASI BACA TULIS SISWA KELAS III SEKOLAH DASAR}

\begin{tabular}{|c|c|}
\hline ARTICLE HISTORY & ABSTRACT \\
\hline $\begin{array}{l}\text { Submitted: } \\
07 \text { Mei } 2021 \\
07^{\text {th }} \text { May } 2021\end{array}$ & $\begin{array}{l}\text { Abstract: This study aimed to develop trilingual smartbook media, to determine the feasibility } \\
\text { of the trilingual smartbook, and to determine students' responses to trilingual smartbook. This } \\
\text { research was conducted on } 10 \text { students at grade III of elementary school in a limited trial. This } \\
\text { research utilized the Borg and Gall model which consisted of six stages, namely problem } \\
\text { analysis, data collection, product design, design validation, design revision, and limited } \\
\text { product trial. The instruments were a questionnaire sheet for product validation by expert } \\
\text { lecturers and a questionnaire sheet for students' responses. Based on the analysis, the quality } \\
\text { of the trilingual smartbook was categorized as very feasible with a percentage of } 91 \% \text { by two } \\
\text { media experts, very feasible with a percentage of } 92 \% \text { by two material experts, and a feasible } \\
\text { category with a percentage of } 80 \% \text { by two linguists. Moreover, the students' response to the } \\
\text { trilingual smartbook was } 96 \% \text { with a very good category. Based on this, it can be said that the } \\
\text { trilingual smartbook is appropriate to be used as a media of literacy facility for third grade } \\
\text { elementary school students. }\end{array}$ \\
\hline
\end{tabular}

Keywords: literacy, trilingual smartbook

Accepted:

10 September 2021

$10^{\text {th }}$ September 2021

Published:

25 Oktober 2021

$25^{\text {th }}$ October 2021
Abstrak: Penelitian ini bertujuan untuk mengetahui cara mengembangkan media buku pintar trilingual, untuk mengetahui kelayakan media buku pintar trilingual, dan untuk mengetahui respons peserta didik terhadap media buku pintar trilingual. Penelitian ini dilakukan dengan sampel penelitian peserta didik kelas III sekolah dasar sejumlah 10 orang pada uji coba terbatas. Jenis penelitian ini mengacu pada model Borg and Gall yang dimodifikasi terdiri dari enam tahap, yaitu analisis masalah, pengumpulan data, desain produk, validasi desain, revisi desain, dan uji coba produk. Instrumen yang digunakan berupa lembar angket untuk validasi produk oleh dosen ahli dan lembar angket untuk respons peserta didik. Berdasarkan analisis data, kualitas buku pintar trilingual yang dikembangkan termasuk kategori sangat layak dengan persentase $91 \%$ dari dua ahli media, kategori sangat layak dengan persentase $92 \%$ dari dua ahli materi, dan kategori layak dengan persentase $80 \%$ dari dua ahli bahasa. Respons peserta didik terhadap buku pintar trilingual pada uji coba dengan 10 responden sebesar $96 \%$ dengan kategori sangat baik. Berdasarkan hal tersebut, dapat disimpulkan bahwa buku pintar trilingual layak digunakan sebagai salah satu sarana literasi baca tulis untuk siswa kelas III sekolah dasar.

Kata Kunci : literasi baca tulis, buku pintar trilingual

\section{CITATION}

Umyati, R., Yuliana, R., \& Rosidin, O. (2021). Developing Trilingual Smart Book Media as a Literacy Facility for Third Grade Students of Elementary School. Primary: Jurnal Pendidikan Guru Sekolah Dasar, 10 (5), 1091-1103. DOI: http://dx.doi.org/10.33578/jpfkip.v10i5.8294. 


\section{PENDAHULUAN}

Kurikulum 2013 ditujukan agar generasi muda unggul, berkarakter, dan menjadi insan yang mampu beradaptasi serta berkompetisi secara global sehingga dapat mendukung kemajuan peradaban bangsa. Namun, hal itu belum terlihat pencapaiannya, dilihat dari hasil perolehan PISA (The Programme for International Student Assesment) pada tahun 2018 Indonesia masih di bawah standar ratarata OECD (Organitation for Economic Cooperation and Development) Indonesia menempati peringkat 74 dari 79 negara. Skor membaca siswa Indonesia hanya 371 (OECD, 2019b). Skor itu sangat jauh dari rata-rata OECD, yakni 487 (OECD, 2019a). Hasil itu menunjukkan penurunan yang signifikan dibandingkan hasil PISA pada tahun 2015, yaitu dengan skor 397 (OECD, 2015).

Menteri Pendidikan dan Kebudayaan, Nadiem Anwar Makarim dalam pidatonya menyatakan bahwa masalah literasi sangat penting dan perlu menjadi sorotan karena Indonesia sedang mengalami krisis literasi (KEMENDIKBUD RI, 2019). Literasi bukan hanya terbatas pada membaca dan menulis, namun melibatkan kemampuan berpikir kritis peserta didik terhadap informasi. Kunci dari literasi sebenarnya, yaitu mencintai membaca karena membaca adalah gerbang dari segala ilmu pengetahuan. Hal itu yang mendasari program Gerakan Literasi Nasional (GLN). Salah satu bentuk dukungan untuk kelancaran pembiasaan literasi di sekolah, yaitu dengan menyediakan buku bacaan yang menarik sehingga dapat menggerakkan gairah peserta didik dalam membaca. Namun, menurut Syahidi (2020) menyatakan bahwa pengelolaan perpustakaan di Banten jenjang sekolah dasar masih berkutat seputar peminjaman buku paket. Masih jauh dari harapan terlebih lagi jarang tersedia buku bacaan yang sesuai untuk karakteristik anak sekolah dasar.

Penguasaan segala bidang studi bermula pada literasi dan sangat bergantung pada bahasa, baik secara lisan maupun tulis. Literasi tidak bisa dipisahkan dengan bidang ilmu bahasa karena bahasa merupakan alat untuk memperoleh dan menyebarluaskan pengetahuan. Alwasilah (2014) menyatakan bahwa manusia setidaknya harus menguasai tiga bahasa, yaitu bahasa daerah, bahasa nasional, dan bahasa internasional.

Berkenaan dengan uraian-uraian di atas, Nuha et al. (2019) menyatakan bahwa kemampuan literasi yang meliputi kemampuan berpikir, membaca, dan menulis harus dimiliki setiap manusia sebagai syarat berkomunikasi dengan individu lain karena ketiga kemampuan tersebut ialah bagian dari hak paling dasar manusia yang berkaitan dengan pembelajaran sepanjang hayat. Kemampuan literasi perlu dituntun oleh semua pihak, meliputi pihak keluarga, sekolah, dan masyarakat.

Literasi di sekolah dilaksanakan berdasarkan Permendikbud yang menggaungkan Gerakan Literasi Sekolah (GLS), program menjadikan warga dengan lingkungan sekolah yang literat. Hal itu tertuang dalam Peraturan Menteri Nomor 23 Tahun 2015 tentang Penumbuhan Budi Pekerti yang di dalamnya tersurat mengenai pembiasaan budaya literasi (Antoro, 2017). Gerakan penumbuhan literasi menjadi perhatian penting bagi bangsa Indonesia.

Berdasarkan hasil wawancara dan observasi pada Selasa, 20 Oktober 2020, prapenelitian di SDIT Mandiri Serang-Banten, diketahui di sekolah tersebut sudah berjalan kegiatan literasi dalam pembelajaran. Namun, hanya dilakukan dua kali dalam seminggu karena buku bacaan di sekolah tersebut kurang bervariasi dan belum ada media membaca yang mencakup tiga bahasa sehingga peserta didik kesulitan dalam mempelajari bahasa. Oleh karena itu, dilakukan pengembangan media buku pintar trilingual.

Buku pintar trilingual yang dikembangkan termasuk ke dalam media visual dua dimensi. Hal itu didukung oleh pernyataan Sundayana (2014) bahwa media 2D adalah media yang dapat dilihat satu arah pandang. Sejalan dengan Arsyad (2017) 
menyatakan bahwa media visual merupakan media yang dapat dilihat, seperti buku, komik, dan gambar. Pemilihan jenis media buku yang bergambar bertujuan untuk menarik perhatian peserta didik dalam pembelajaran. Senada dengan pernyataan Yuliana (2018) menyatakan bahwa media pembelajaran yang menggunakan gambar berfungsi sebagai daya tarik dan dapat mengembangkan imajinasi peserta didik.

Penelitian yang relevan dengan penelitian dan pengembangan ini, diantaranya yaitu penelitian yang ditulis oleh Suharto \& Solihati (2020) membahas tentang pengintegrasian bahasa asing, khususnya bahasa Inggris dengan budaya lokal pada materi ajar. Penelitian tersebut mengkaji kebutuhan peserta didik dalam tahap pengembangan materi ajar di sekolah dasar. Suharto \& Solihati (2020) menyatakan bahwa pembelajar bahasa asing pada usia dini menjadi prioritas dalam pengajaran berbasis budaya lokal sehingga pembelajar tidak akan kehilangan jati diri budayanya. Selain mendukung kebijakan pemerintah dalam mendukung gerakan literasi, penelitian tersebut membantu pendidik dalam memfasilitasi peserta didik untuk meningkatkan kemampuan bahasa Inggris dan pengetahuan budaya lokal secara bersamaan. Penelitian lainnya ditulis oleh Khotimah (2020) membahas tentang pengembangan produk berupa buku dwibahasa sebagai sarana apresiasi sastra menggunakan model Borg dan Gall. Produk buku dwibahasa tersebut dikembangkan guna menarik perhatian peserta didik untuk membaca dan mengapresiasi buku bacaan.

Produk yang dikembangkan oleh penulis adalah buku pintar trilingual sebagai sarana literasi baca tulis. Berbeda dengan penelitian yang disebutkan sebelumnya, penelitian ini lebih fokus pada literasi baca tulis. Selain itu, produk dirancang dengan menyajikan gambar dan teks yang menggunakan tiga bahasa, yaitu bahasa Jawa dialek Banten, bahasa Indonesia, dan bahasa Inggris. Dilihat dari penelitian terdahulu, diketahui tidak ada yang membahas khusus mengenai produk yang penulis kembangkan sehingga dapat disimpulkan bahwa penelitian ini belum banyak dilakukan dan tergolong baru.

Konsep buku pintar trilingual diadaptasi dari buku cerita bergambar karena menyajikan gambar dan teks dalam buku sehingga dapat membantu peserta didik memahami isi bacaan. Pernyataan itu didukung oleh Gustanti (2018) bahwa buku cerita bergambar disajikan dengan teks yang dilengkapi dengan gambar untuk membantu peserta didik dalam memahami isinya. Buku bacaan literasi dapat diwujudkan melalui buku pintar trilingual yang menyajikan teks dan gambar sebagai sarana literasi. Hal itu senada dengan Rohman (2017) menyatakan bahwa buku bacaan bergambar akan menarik perhatian peserta didik untuk membuka dan memperhatikan isi buku.

Buku pintar trilingual dihasilkan melalui modifikasi pada tiga bagian utama yang tersusun dalam buku pintar trilingual, yaitu (1) bagian pembendaharaan kata atau vocabulary menggunakan bahasa Indonesia, bahasa Jawa dialek Banten, dan bahasa Inggris; (2) bagian cerita beserta gambar atau ilustrasi dengan kalimat tiga bahasa dalam satu halaman; dan (3) bagian responding reading.

Tujuan penelitian dan pengembangan ini, yakni (1) mendeskripsikan proses pengembangan buku pintar trilingual sebagai sarana literasi baca tulis siswa kelas III sekolah dasar; (2) mendeskripsikan kelayakan buku pintar trilingual sebagai sarana literasi baca tulis siswa kelas III sekolah dasar; dan (3) mendeskripsikan respons peserta didik terhadap buku pintar trilingual sebagai sarana literasi baca tulis siswa kelas III sekolah dasar.

\section{METODE PENELITIAN}

Penelitian ini dilaksanakan di SDIT Mandiri yang berlokasi di jalan Raya Cilegon Km. 06, Taman Baru, Kota Serang, provinsi Banten. Waktu penelitian yaitu, tujuh bulan terhitung dari November 2020 sampai Mei 2021. Penelitian ini menggunakan metode penelitian dan pengembangan (Reserch and 
Development) dengan tujuan untuk menghasilkan produk media berupa buku pintar trilingual sebagai sarana literasi baca tulis siswa kelas III sekolah dasar. Desain penelitian ini menggunakan model Borg dan Gall yang dimodifikasi (Sugiyono, 2017).

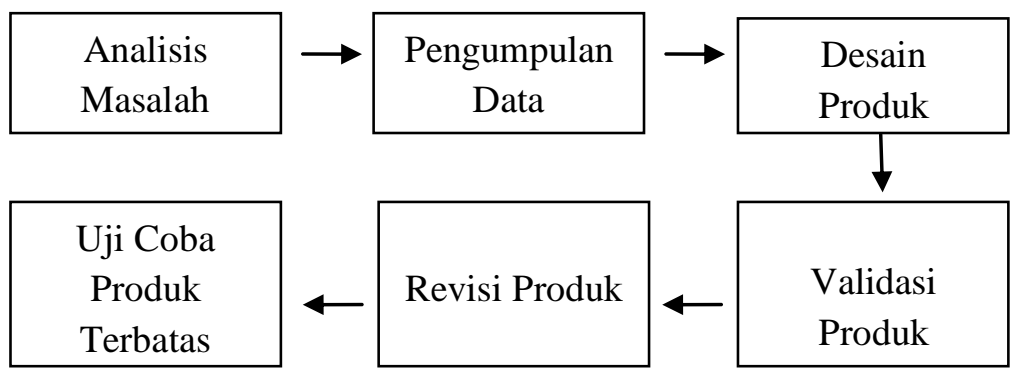

Gambar 1. Alur Modifikasi Metode R\&D (Sugiyono, 2017)

Berdasarkan gambar 1 di atas, prosedur penelitian pengembangan buku pintar trilingual sebagai sarana literasi baca tulis, yaitu sebagai berikut.

\section{Analisis Masalah}

Analisis masalah dilakukan dengan cara studi lapangan guna menganalisis kebutuhan sekolah dasar mengenai media pembelajaran. Analisis kebutuhan dilakukan dengan cara mengumpulkan informasi melalui kegiatan wawancara tidak terstruktur dengan wali kelas III dan observasi ke perpustakaan SDIT Mandiri. Tujuan wawancara untuk mengumpulkan data mengenai pembiasaan literasi, kegiatan pembelajaran, dan media pembelajaran. Sementara itu, tujuan observasi, yaitu mengamati ketersediaan buku bacaan di perpustakaan sekolah dasar.

\section{Pengumpulan Data}

Pengumpulan data dan bahan untuk pembuatan media buku pintar trilingual ditentukan berdasarkan analisis kebutuhan menggunakan wawancara tidak terstruktur dan studi literatur. Selain itu, penelitian ini menggunakan teknik pengumpulan data, yaitu wawancara, observasi, angket, dan dokumentasi.

\section{Desain Produk}

Pembuatan produk didesain menggunakan aplikasi desain grafis berbasis web, yakni Canva. Produk disajikan dengan gambar yang disesuaikan dengan isi bacaan. Pada tahap ini, dirancang pula story board dan angket instrumen validasi. Intrumen validasi digunakan untuk tahap selanjutnya, yaitu validasi produk sehingga dapat diketahui kelayakan produk. Pembuatan desain produk berupa media buku pintar trilingual sebagai sarana literasi baca tulis siswa kelas III sekolah dasar.

\section{Validasi Produk}

Tahap validasi dilakukan guna mengetahui kriteria produk yang telah dikembangkan memenuhi syarat kelayakan produk. Pada tahap ini, penulis meminta pendapat, komentar, dan saran ahli terhadap rancangan buku pintar trilingual. Uji ahli untuk validasi media buku pintar trilingual dilaksanakan dalam tiga kategori dengan masing-masing dua ahli, yaitu ahli media, ahli materi, dan ahli bahasa.

Kisi-kisi instrumen uji ahli media, meliputi komponen buku, verbal, desain sampul, desain isi, tipografi, dan percetakan (Akbar, 2013). Kisi-kisi instrumen uji ahli materi, meliputi isi cerita/bacaan, halaman, dan penyajian (Yuliana, 2018). Kisi-kisi instrumen ahli bahasa, meliputi keterbacaan, kejelasan, kesesuaian, dan pemanfaatan bahasa (Depdiknas, 2008). Kisi-kisi angket respons siswa, meliputi penyajian media, 
penyajian materi, tampilan, dan bahasa (Fitriani, 2019).

Analisis data angket uji ahli dan respons siswa dilakukan berdasarkan kriteria indikator keberhasilan, yaitu memperoleh kriteria persentase 61-80\%. Skor yang diperoleh dihitung dengan menggunakan rumus sebagai berikut:
$\mathrm{NP}=\frac{R}{S M} \times 100 \%$

(Purwanto, 2013)

NP adalah nilai rata-rata (\%), $\mathrm{R}$ adalah skor yang diperoleh dari setiap aspek, dan SM adalah skor maksimum dari seluruh aspek. Nilai yang diperoleh kemudian di interpretasikan sesuai dengan kriteria yang telah ditentukan dalam tabel 1 dan 2 .

Tabel 1. Kriteria Kelayakan Produk

\begin{tabular}{cc}
\hline Presentasi Pencapaian & Kategori Kelayakan \\
\hline $81 \%-100 \%$ & Sangat layak \\
$61 \%-80 \%$ & Layak \\
$41 \%-60 \%$ & Cukup layak \\
$21 \%-40 \%$ & Kurang Layak \\
$0 \%-20 \%$ & Tidak layak \\
\hline
\end{tabular}

Tabel 2. Kriteria Interpretasi Respons Peserta Didik

(Sumber: Modifikasi Purwanto, 2013)

\begin{tabular}{cc}
\hline Presentasi Pencapaian & Kategori Kelayakan \\
\hline $81 \%-100 \%$ & Sangat Baik \\
$61 \%-80 \%$ & Baik \\
$41 \%-60 \%$ & Cukup Baik \\
$21 \%-40 \%$ & Kurang Baik \\
$0 \%-20 \%$ & Tidak Baik \\
\hline
\end{tabular}

(Sumber: Riduwan, 2013)

\section{Revisi Produk}

Pada tahap ini bertujuan untuk memperbaiki kesalahan yang terdapat pada pengembangan buku pintar trilingual. Jika validasi produk dari uji ahli terdapat hal yang perlu diperbaiki, pada tahap ini dilakukan revisi atau perbaikan sehingga produk dapat menjadi produk yang lebih baik. Tahap revisi produk selesai setelah produk yang sudah dikatakan layak diuji cobakan.

\section{Uji Coba Produk Skala Terbatas}

Uji coba terbatas ini dilaksanakan di SDIT Mandiri yang akan diujicobakan kepada 10 peserta didik kelas III. Hal itu dilakukan dengan menggunakan teknik purposive sampling. Pada uji coba terbatas peserta didik diberikan lembar angket untuk mengetahui respons peserta didik terhadap media buku pintar trilingual.

\section{HASIL DAN PEMBAHASAN}

Hasil penelitian R\&D ini berupa produk buku pintar trilingual sebagai sarana literasi baca tulis siswa kelas III sekolah dasar. Penelitian dan pengembangan dilakukan selama tujuh bulan terhitung dari November 2020 hingga Mei 2021. Pengembangan media buku pintar trilingual dilakukan dalam beberapa tahap, yakni analisis masalah, pengumpulan data, desain produk, validasi desain produk, revisi produk, dan uji coba produk.

\section{a. Analisis Masalah}

Analisis masalah dilakukan dengan menganalisis kebutuhan dengan cara mengumpulkan informasi melalui kegiatan wawancara tidak terstruktur dengan guru kelas III dan observasi ke perpustakaan SDIT Mandiri. Berdasarkan hasil wawancara, diketahui bahwa SDIT Mandiri sudah 
menerapkan pembiasaan literasi. Namun, buku bacaan literasi di sekolah tersebut kurang bervariasi, terlebih buku bacaan yang menggunakan bahasa daerah dan bahasa internasional. Peserta didik kesulitan dalam pembelajaran bahasa Jawa dialek Banten dan bahasa Inggris karena keterbatasan buku bacaan sebab yang tersedia hanya buku paket dan LKS.

Berdasarkan observasi ke perpustakaan SDIT Mandiri, penulis mengamati bahwa buku paket mendominasi dan sudah ada buku bacaan literasi yang menggunakan bahasa Indonesia di perpustakaan SDIT Mandiri. Namun, penulis melihat buku bacaan literasi yang menggunakan bahasa Inggris hanya satu jenis dan tidaklah banyak. Penulis tidak melihat buku bacaan literasi yang menggunakan bahasa Jawa dialek Banten.

Oleh karena hal tersebut, penulis mengembangkan media buku pintar trilingual sebagai sarana literasi baca tulis. Pengembangan produk tersebut diharapkan dapat menumbuhkan rasa cinta peserta didik terhadap membaca dan menambah sumber belajar bagi peserta didik.

\section{b. Pengumpulan Data}

Tahap pengumpulan data dan bahan dalam pembuatan media buku pintar trilingual yang ditentukan berdasarkan analisis masalah. Data yang dikumpulkan berupa studi literatur dari data analisis kebutuhan menggunakan wawancara tidak terstruktur kepada wali kelas III SDIT Mandiri melalui 10 pertanyaan, terkait literasi, kegiatan pembelajaran, dan media pembelajaran. Studi literatur dapat mengumpulkan berbagai informasi yang ditemukan sehingga dapat dijadikan bahan untuk mengembangkan produk.

\section{c. Desain Produk}

Pengembangan produk yang dihasilkan pada penelitian ini berupa buku pintar trilingual. Buku pintar trilingual didesain menggunakan aplikasi desain grafis berbasis web, yakni Canva. Buku pintar trilingual disajikan dengan gambar dan teks yang dibuat oleh penulis dengan mempertimbangkan hal-hal tertentu, yaitu sebagai berikut: (1) peserta didik menyukai gambar yang berwarna dan (2) pihak sekolah memberikan arahan untuk isi bacaan dikemas dalam cerita yang menarik dikaitkan dengan materi pada buku tematik sehingga peserta didik mendapatkan pengetahuan baru. Materi buku pintar trilingual berkaitan dengan Tema 6 Indahnya Persahabatan Subtema 2 Tumbuhan Sahabatku Pembelajaran ke 4 kelas III sekolah dasar. Ukuran buku pintar trilingual adalah A4 $(21 \mathrm{~cm} \times 29,7 \mathrm{~cm})$ berjumlah 22 halaman dengan orientasi halaman portrait. Bentuk buku pintar trilingual berupa buku cetakan menggunakan jenis kertas art paper dan buku digital secara daring menggunakan $Q R$ Code.

Penulis memilih aplikasi desain grafis berbasis web (Canva) untuk merancang desain produk dikarenakan aplikasi Canva dapat memudahkan penulis dalam penyusunan buku pintar trilingual. Aplikasi Canva menyediakan fitur-fitur yang dapat digunakan secara gratis, diantaranya fitur template, unggahan, foto, eleman, teks, audio, video, folder, gaya, bagan, dan fitur lainnya yang terintegrasi dengan aplikasi-aplikasi lain. Penulis memanfaatkan template yang dimodifikasi untuk cover, elemen untuk gambar, pilihan teks yang bervariasi, dan pembuatan $Q R$ Code melalui tools lainnya. Penulis dapat memanfaatkan fitur-fitur yang ada pada aplikasi Canva secara gratis melalui laptop yang tersambung dengan internet selama pembuatan desain produk. Gambar 2 menunjukkan tampilan halaman kerja aplikasi yang menyediakan fitur-fitur dalam pembuatan buku pintar trilingual. 


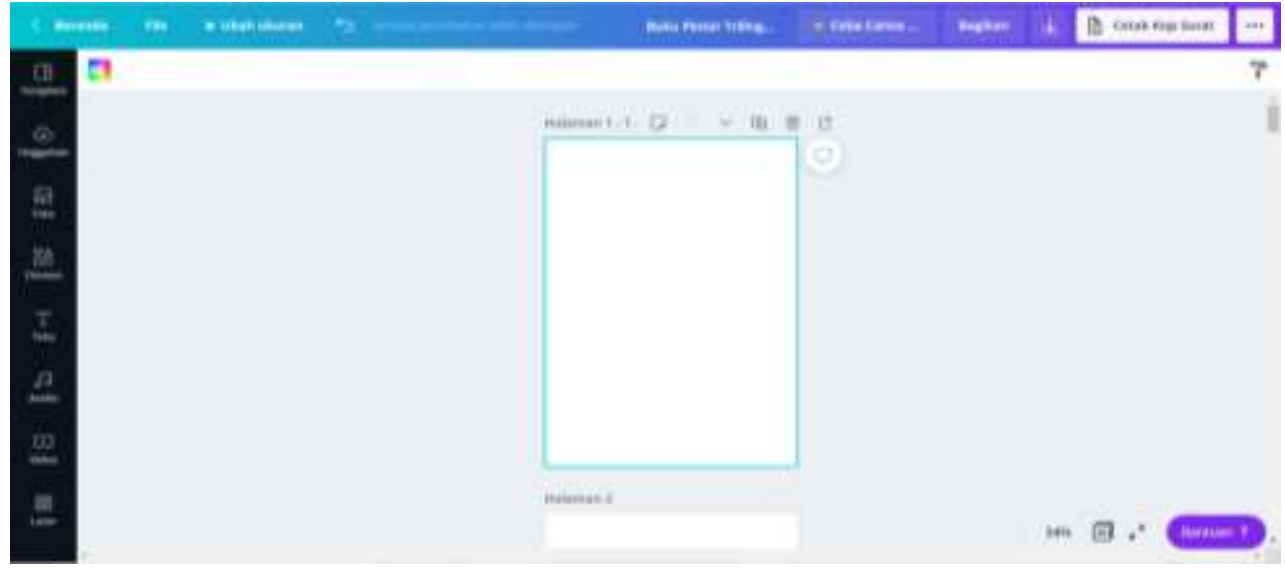

Gambar 2. Tampilan Halaman Kerja Aplikasi

Buku pintar trilingual terdapat tiga bagian utama, yaitu (1) bagian kosakata tiga bahasa agar peserta didik memiliki atau menambah perbendaharaan kata sebelum pembelajaran; (2) bagian cerita yang didukung dengan gambar sesuai dengan kalimat tiga bahasa dalam satu halaman; dan (3) bagian responding reading melalui beberapa pertanyaan. Tiga bahasa yang digunakan dalam buku pintar trilingual, yaitu bahasa Indonesia, bahasa Jawa dialek Banten, dan bahasa Inggris. Gambar 3 di bawah ini menunjukkan masing-masing bagian dari tiga bagian utama dari buku pintar trilingual.
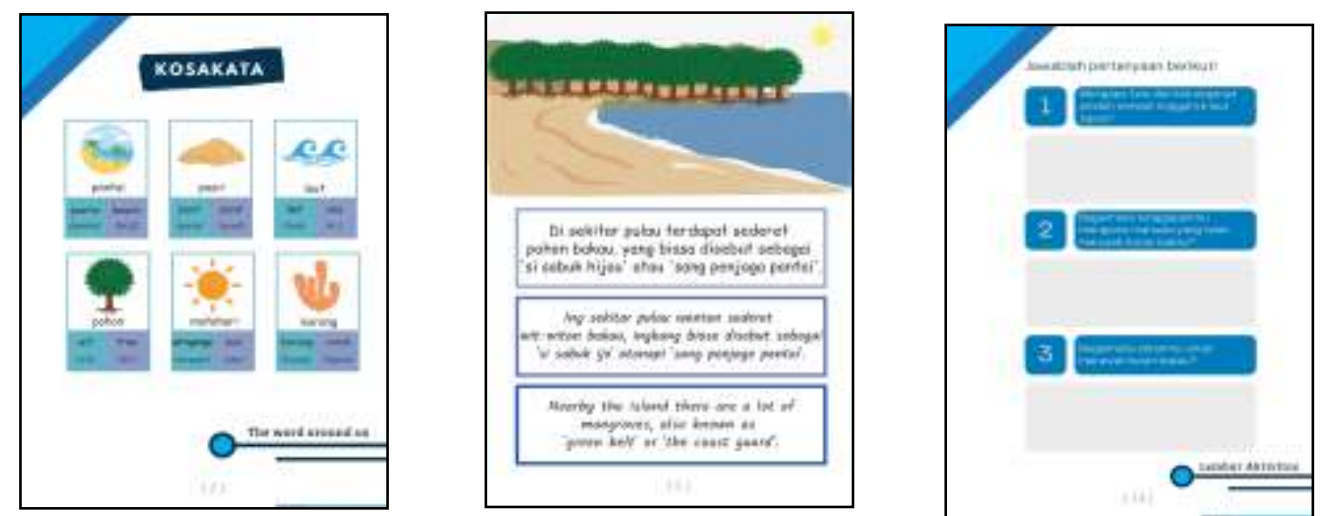

Gambar 3. Tiga Bagian Utama Buku Pintar Trilingual

Keseluruhan gambar yang digunakan dalam buku pintar trilingual dirancang melalui aplikasi Canva dengan pemilihan gambar menggunakan keyword tertentu pada fitur elemen yang dapat diedit dan disesuaikan dengan isi bacaan. Gambar diedit dengan fitur ubah warna, pangkas, balik, letak posisi, salin gaya, dan transparansi. Pilihan gambar pada fitur elemen lebih banyak pilihan gambar yang tersedia dengan memasukkan kata kunci menggunakan bahasa Inggris. Pemilihan gambar disesuaikan dengan karakteristik peserta didik sekolah dasar. Penulis memilih gambar dengan warna yang cerah. Warna yang terdapat pada buku pintar trilingual adalah warna-warna pelangi (full color) agar menambah ketertarikan pada buku pintar trilingual.

Jenis huruf yang digunakan pada buku pintar trilingual, yaitu Bree Serif, League Spartan, Open Sans, Comic Relief, Times New Roman, Kalam Light, dan Telegraf. Bree Serif 
digunakan untuk keterangan pada halaman depan, pembatas pada setiap kategori bagian kosakata, dan pembatas bagian lembar aktivitas. League Spartan digunakan untuk judul buku. Open Sans yang memiliki variasi extra bold dan light digunakan untuk huruf pada identitas buku, kata pengantar, daftar isi, daftar pustaka, biodata, dan keterangan pada halaman belakang. Comic Relief digunakan untuk bagian kosakata dan pengantar cerita bahasa Indonesia. Times New Roman digunakan untuk huruf pada pelafalan bunyi kosakata bahasa Jawa dialek Banten dan bahasa Inggris. Kalam Light digunakan untuk pengantar cerita bahasa Jawa dialek Banten dan bahasa Inggris. Telegraf digunakan untuk huruf pada pertanyaan yang ada di lembar aktivitas.
Kata atau kalimat tiga bahasa pada buku pintar trilingual menggunakan jenis huruf yang berbeda. Pemilihan jenis huruf disertakan dengan pemilihan warna, ukuran, efek, jarak, dan spasi. Ukuran huruf yang digunakan sekitar 14 - 48. Warna pada huruf disesuaikan dengan warna background atau latar belakang. Hal itu dilakukan agar huruf dapat terlihat dengan jelas sehingga mudah untuk dibaca.

\section{d. Validasi Produk}

Validasi produk diajukan kepada para ahli yang berkompeten dalam bidang media, materi, dan bahasa. Validasi produk bertujuan untuk mengetahui kelayakan buku pintar trilingual sebagai sarana literasi baca tulis siswa kelas III sekolah dasar. Adapun hasil validasi produk terdapat pada tabel di bawah ini.

Tabel 3. Hasil Penilaian Tim Ahli Media

\begin{tabular}{clccc}
\hline \multirow{2}{*}{ Uji Ahli } & \multicolumn{1}{c}{ Aspek } & \multicolumn{2}{c}{ Skor } & Np (\%) \\
Total
\end{tabular}

Berdasarkan tabel hasil penilaian tim ahli media di atas, didapatkan skor dari ahli media I sebesar 97 dari jumlah skor maksimal 110 dengan persentase sebesar $88 \%$. Sementara itu, jumlah skor dari ahli media II sebesar 94 dari jumlah skor maksimal 110 dengan persentase sebesar 94\%. Rata-rata penilaian validasi media dari dua ahli tersebut sebesar 91\% termasuk ke dalam kategori "sangat layak" berdasarkan kriteria interpretasi uji kelayakan menurut Purwanto (2013).

Tabel 4. Hasil Penilaian Tim Ahli Materi

\begin{tabular}{ccccc}
\hline \multirow{2}{*}{ Uji Ahli } & \multicolumn{1}{c}{ Aspek } & Ahli Materi I & Ahli Materi II & $\begin{array}{c}\text { Np (\%) } \\
\text { Total }\end{array}$ \\
\hline Ahli Materi & $\begin{array}{l}\text { Isi cerita/bacaan, halaman, } \\
\text { dan penyajian. } \\
\text { Kriteria Kelayakan }\end{array}$ & $92 \%$ & $93 \%$ & $92 \%$ \\
\hline
\end{tabular}

Berdasarkan tabel hasil penilaian tim ahli materi di atas, didapatkan skor dari ahli materi I sebesar 55 dari jumlah skor maksimal 60 dengan persentase sebesar 92\%. Sementara itu, jumlah skor dari ahli materi II sebesar 56 dari jumlah skor maksimal 60 dengan persentase sebesar 93\%. Rata-rata penilaian validasi materi dari dua ahli tersebut sebesar $92 \%$ termasuk ke dalam kategori "sangat 
Tabel 5. Hasil Penilaian Tim Ahli Bahasa

\begin{tabular}{clccc}
\hline \multirow{2}{*}{ Uji Ahli } & \multicolumn{1}{c}{ Aspek } & Ahli Bahasa I & Ahli Bahasa II & Np (\%) \\
Total
\end{tabular}

Berdasarkan tabel hasil penilaian tim ahli bahasa di atas, didapatkan skor dari ahli bahasa I sebesar 50 dari jumlah skor maksimal 60 dengan persentase sebesar $83 \%$. Sementara itu, jumlah skor dari ahli bahasa II sebesar 46 dari jumlah skor maksimal 60 dengan persentase sebesar $77 \%$. Rata-rata penilaian validasi bahasa dari dua ahli tersebut sebesar $80 \%$ termasuk ke dalam kategori "layak" berdasarkan kriteria interpretasi uji kelayakan menurut Purwanto (2013).

\section{e. Revisi Produk}

Setelah produk divalidasi oleh para ahli, ada beberapa beberapa komentar dan saran yang diberikan guna menyempurnakan buku pintar trilingual yang dijabarkan pada tabel di bawah ini.

Tabel 6. Komentar dan Saran oleh Ahli Media

\begin{tabular}{ccl}
\hline No & Validator & \multicolumn{1}{c}{ Komentar dan Saran } \\
\hline 1. & Ahli media I & $\begin{array}{l}\text { Media yang dibuat sangat bagus. Namun, ada yang perlu diperbaiki, } \\
\text { yaitu memunculkan nama pembimbing pada cover, ditambahkan } \\
\text { biodata pembimbing, dan perbaiki kata pengantar. } \\
\text { 2. }\end{array}$ \\
& Ahli media II & $\begin{array}{l}\text { Media sudah sesuai dengan kriteria uji validasi dan sesuai dengan } \\
\text { karakteristik peserta didik. Media akan lebih baik lagi bila kesesuaian } \\
\text { kata lebih diperhatikan. }\end{array}$ \\
\hline
\end{tabular}

Tabel 7. Komentar dan Saran oleh Ahli Materi

\begin{tabular}{ccl}
\hline No & Validator & \multicolumn{1}{c}{ Komentar dan Saran } \\
\hline 1. & Ahli materi I & Lanjutkan ke tahap berikutnya. \\
2. & Ahli materi II & $\begin{array}{l}\text { Isi bacaan sangat menarik untuk dibaca. Buku pintar trilingual layak } \\
\text { digunakan tanpa revisi. }\end{array}$ \\
\hline
\end{tabular}

Tabel 8. Komentar dan Saran oleh Ahli Bahasa

\begin{tabular}{ccl}
\hline No & Validator & \multicolumn{1}{c}{ Komentar dan Saran } \\
\hline 1. & Ahli bahasa I & $\begin{array}{l}\text { Buku pintar trilingual sesuai dengan sasaran pembaca dan tata kalimat } \\
\text { cukup sederhana. Sebaiknya perbaiki simbol untuk kosakata bahasa }\end{array}$ \\
& & $\begin{array}{l}\text { Inggris dan kesesuaian kalimat dengan kaidah bahasa. } \\
\text { Buku pintar trilingual yang dibuat mampu menarik pembaca. Ada } \\
\text { beberapa catatan yang perlu diperhatikan, yaitu kompleksitas kalimat } \\
\text { yang digunakan, memperbaiki pelafalan cara baca kosakata bahasa } \\
\text { Inggris, menambahkan cara baca kosakata bahasa Jawa dialek Banten, } \\
\text { dan mempertimbangkan konsistensi tenses. }\end{array}$ \\
\hline
\end{tabular}

\section{f. Uji Coba Produk}

Uji coba produk skala terbatas dilakukan melalui pertemuan langsung dengan
10 siswa kelas III SDIT Mandiri. Siswa diberikan lembar angket untuk mengetahui respons siswa terhadap buku pintar trilingual. 
Tabel 9. Hasil Respons Siswa

\begin{tabular}{|c|c|c|c|c|}
\hline \multicolumn{4}{|c|}{ Aspek Penilaian } & \multirow{2}{*}{ NP (\%) } \\
\hline Penyajian Media & Penyajian Materi & Tampilan & Bahasa & \\
\hline $98 \%$ & $90 \%$ & $100 \%$ & $98 \%$ & $96 \%$ \\
\hline
\end{tabular}

Berdasarkan tabel hasil respons siswa di atas, media buku pintar trilingual yang telah diujicobakan, diperoleh rata-rata nilai keseluruhan respons siswa sebesar 96\% termasuk ke dalam kategori "sangat baik" berdasarkan kriteria interpretasi respons siswa menurut (Riduwan, 2013).

\section{Pembahasan}

Pengembangan media buku pintar trilingual dilakukan dalam beberapa tahap, yakni analisis masalah, pengumpulan data, desain produk, validasi desain produk, revisi produk, dan uji coba produk. Tahap awal penelitian, yaitu analisis masalah dilakukan dengan analisis kebutuhan melalui wawancara dan observasi untuk mengetahui permasalahan atau kebutuhan peserta didik dalam pembelajaran.

Berdasarkan hasil wawancara dan observasi, penulis mengembangkan media buku pintar trilingual sebagai sarana literasi baca tulis. Pengembangan produk tersebut diharapkan dapat menumbuhkan rasa cinta peserta didik terhadap membaca dan menambah sumber belajar bagi peserta didik. Hal itu mendukung program Kemdikbud yang mencanangkan Gerakan Literasi Sekolah (GLS) yang merupakan program untuk menjadikan lingkungan sekolah dengan warga yang literat (Atmazaki et al., 2017).

Pada tahap desain produk, buku pintar trilingual didesain menggunakan aplikasi desain grafis berbasis web, yakni Canva. Materi yang dibuat untuk isi bacaan buku pintar trilingual berkaitan dengan Tema 6 Subtema 2 Pembelajaran ke 4 kelas III sekolah dasar. Buku pintar trilingual disajikan dengan gambar dan teks yang dibuat oleh penulis dengan mempertimbangkan hal-hal tertentu. Konsep buku pintar trilingual diadaptasi dari buku cerita bergambar yang menyajikan gambar dan teks agar peserta didik memahami isi bacaan. Hal itu sejalan dengan (Gustanti, 2018) yang menyatakan bahwa buku cerita bergambar disajikan dengan teks yang dilengkapi dengan gambar untuk membantu peserta didik dalam memahami isinya.

Bentuk media buku pintar trilingual berupa buku cetakan menggunakan jenis kertas art paper dan buku digital secara daring menggunakan $Q R$ Code. Hal itu sejalan dengan pernyataan Kusumaningtyas et al. (2018) mengenai klasifikasi media yang dapat berbentuk cetakan yang melewati proses percetakaan dan noncetak yang menggunakan teknologi. Bentuk media dapat disesuaikan dengan kebutuhan pembelajaran.

Buku pintar trilingual terdapat tiga bagian utama, yaitu (1) bagian kosakata tiga bahasa agar peserta didik memiliki atau menambah perbendaharaan kata sebelum pembelajaran, (2) bagian cerita yang didukung dengan gambar sesuai dengan kalimat tiga bahasa dalam satu halaman, dan (3) bagian responding reading melalui beberapa pertanyaan. Hal tersebut mempetimbangkan karakteristik perkembangan literasi anak, khususnya peserta didik kelas III sekolah dasar yang dikemukakan oleh Abidin (2015), yaitu peserta didik masih menggunakan gambar dan teks untuk memahami bacaan, serta memahami kosakata baru melalui kata kunci.

Buku pintar trilingual yang telah jadi belum menjadi produk akhir yang layak untuk di ujicobakan, perlu melalui tahap validasi dari para ahli, yakni dua ahli media, dua ahli bahasa, dan dua ahli materi. Kelayakan media buku pintar trilingual secara keseluruhan dari hasil validasi produk mendapatkan persentase sebesar $88 \%$ sehingga dapat dikategorikan ke dalam kategori "sangat layak". 
Penilaian ahli media berlangsung bersamaan dengan tahap revisi produk. Penilaian kedua ahli media dan masukan yang didapat untuk memperbaiki produk, buku pintar trilingual yang dikembangkan berada dalam kategori yang sangat layak untuk diujicobakan di sekolah dasar, hasil penggabungan penilaian kedua ahli media, yakni mencapai persentase $91 \%$ dengan kategori "Sangat Layak". Sementara itu, penilaian dari kedua ahli materi yang didapat termasuk ke dalam kategori yang sangat layak untuk diujicobakan tanpa revisi, hasil penggabungan penilaian kedua ahli media yakni mencapai persentase $92 \%$ dengan kategori "Sangat Layak". Dari penilaian kedua ahli bahasa dan masukan yang didapat untuk memperbaiki produk, didapatkan buku pintar trilingual dengan kategori yang layak untuk diujicobakan di sekolah dasar, hasil penggabungan penilaian kedua ahli media, yakni mencapai persentase $80 \%$ dengan kategori "Layak".

Setelah tahap validasi dan revisi produk selesai, tahap selanjutnya ialah uji coba produk skala terbatas. Uji coba produk dilakukan secara luring di kelas III SDIT Mandiri yang melibatkan 10 siswa dengan memperhatikan protokol kesehatan yang dianjurkan pemerintah. Persentase nilai akhir angket respons siswa terhadap buku pintar trilingual, yaitu sebesar 96\%. Berdasarkan tabel kriteria interpretasi respons peserta didik yang dikemukakan Riduwan (2013), respons peserta didik terhadap media buku pintar trilingual termasuk ke dalam kategori "Sangat Baik". Hasil itu menunjukkan bahwa semua indikator, meliputi aspek penyajian media, penyajian materi, tampilan, dan bahasa telah terpenuhi dengan sangat baik.

Penulis menemukan temuan penelitian dan pengembangan berupa kelebihan dan kekurangan dari pelaksanaan pembelajaran menggunakan buku pintar trilingual. Komponen gambar pada buku pintar trilingual mudah didapat menggunakan aplikasi Canva yang dapat disesuaikan dengan isi bacaan sehingga masuk dalam materi pembelajaran. Hal itu sejalan dengan pernyataan Uno \& Lamatenggo (2011) bahwa kelebihan media gambar, yaitu gambar dapat diperoleh, dapat memperjelas suatu hal yang dipelajari, dan dapat digunakan pada setiap tema pembelajaran. Selain itu, saat uji coba produk terbatas, peserta didik terlihat antusias melihat gambar berwarna yang disajikan, peserta didik terlihat senang, dan peserta didik memiliki inisiatif membacakan teks pada bagian tertentu dalam buku pintar trilingual. Hal itu berkesesuaian dengan Fitriani (2019) bahwa media gambar khususnya pada buku cerita bergambar memiliki kelebihan, yaitu dapat digunakan dalam semua pembelajaran karena adanya gambar yang berwarna dan cerita yang menarik dapat memotivasi peserta didik untuk belajar, mendorong minat baca, memudahkan peserta didik dalam memahami materi, dan mengingat isi bacaan.

Kekurangan pada buku pintar trilingual, yaitu tidak dapat digunakan untuk kelompok besar. Hal itu berkesuaian dengan Anitah W. et al. (2014) yang menyatakan bahwa media gambar yang berukuran kecil tidak dapat digunakan untuk banyak siswa atau kelas besar. Oleh karena itu, penulis menyediakan buku pintar trilingual untuk masing-masing siswa sehingga memerlukan lebih banyak biaya percetakan. Selain itu, saat uji coba terbatas, peserta didik lebih memperhatikan gambar dari pada teks pada buku pintar trilingual. Hal itu sejalan dengan Sribudi (2018) bahwa media buku yang bergambar memiliki kekurangan, yakni pembaca lebih fokus pada gambar daripada teks.

\section{SIMPULAN DAN REKOMENDASI}

Berdasarkan hasil dan pembahasan penelitian, penulis dapat mengemukakan simpulan sebagai berikut.

1. Proses pengembangan buku pintar trilingual sebagai sarana literasi baca tulis siswa kelas III sekolah dasar ini dilakukan dengan menggunakan model Borg dan 
Gall yang dimodifikasi (Sugiyono, 2017) yang diberikan batasan pada model, yaitu sampai enam tahapan meliputi (a) analisis masalah, (b) pengumpulan data, (c) desain produk, (d) validasi desain, (e) revisi desain, dan (f) uji coba produk. Tahap validasi desain dilakukan bersamaan dengan revisi desain dalam satu kali tahapan. Hal itu mempertimbangkan efesiensi waktu, minimalisasi biaya, kesediaaan validator, dan hasil validasi desain produk mencapai indikator keberhasilan penelitian.

2. Berdasarkan tinjauan perhitungan hasil validasi produk dalam tiga kategori, yaitu ahli media, ahli materi, dan ahli bahasa, ditemukan kelayakan buku pintar trilingual sebagai sarana literasi baca tulis siswa kelas III sekolah dasar yang memenuhi indikator keberhasilan penelitian. Adapun tingkat kelayakan buku pintar trilingual ini ditunjukkan oleh perolehan persentase $91 \%$ dari dua ahli media, $92 \%$ dari dua ahli materi, dan $80 \%$ dari dua ahli bahasa. Nilai rata-rata keseluruhan validasi ahli sebesar $88 \%$ yang diperoleh sehingga dikategorikan ke dalam kategori "sangat layak".

3. Berdasarkan pengolahan data respons peserta didik terhadap buku pintar trilingual sebagai sarana literasi baca tulis siswa kelas III sekolah dasar pada uji coba lapangan dalam skala terbatas yang melibatkan 10 peserta didik, ditemukan hasil respons peserta didik memenuhi indikator keberhasilan penelitian dengan tingkat respons peserta didik diperoleh persentase $96 \%$ sehingga dapat dikategorikan ke dalam kategori "sangat baik".

Berdasarkan hasil penelitian dan kesimpulan di atas, diajukan rekomendasi sebagai berikut.

1. Bagi pendidik, untuk menambah referensi dalam pembiasaan literasi dan pembelajaran bahasa di sekolah dasar, pendidik disarankan menggunakan buku pintar trilingual yang disesuaikan topik bahasan dalam pembelajaran.

2. Bagi sekolah, untuk menambah buku bacaan yang variatif, pihak sekolah disarankan menggunakan aplikasi Canva untuk membuat bahan bacaan seperti buku pintar trilingual.

Bagi peneliti yang akan mengembangkan buku pintar trilingual, disarankan mengembangkan buku pintar trilingual dalam versi digital dengan memberikan efek gerak pada gambar dan menambahkan fitur audio sehingga versi digital lebih menarik dan peserta didik dapat mendengarkan suara dalam tiga bahasa.

\section{DAFTAR PUSTAKA}

Abidin, Y. (2015). Pembelajaran Multiliterasi Sebuah Jawaban atas Tantangan Pendidikan Abad Ke-21 dalam Konteks Keindonesiaan. Jakarta: Refika Aditama.

Akbar, S. (2013). Instrumen Perangkat Pembelajaran. Bandung: Remaja Rosdakarya.

Alwasilah, A. C. (2014). Filsafat Bahasa dan Pendidikan. Bandung: Remaja Rosdakarya.

Anitah W., S., Hernawan, A. H., Ruhimat, T., Wardani, I. G. A. K., \& Julaeha, S. (2014). Materi Pokok Srtategi Pembelajaran di SD (Ed. 1). Jakarta: Universitas Terbuka.

Antoro, B. (2017). Gerakan Literasi Sekolah: Dari Pucuk Hingga Akar. Jakarta: Direktorat Jendral Manajemen Pendidikan Dasar dan Menengah Kementrian Pendidikan dan Kebudayaan. Arsyad, A. (2017). Media Pembelajaran. Jakarta: Rajawali Pers.

Atmazaki, Ali, N. B. V., Muldian, W., Miftahussururi, Hanifah, N., Nento, M. N., \& Akbari, Q. S. (2017). Panduan Gerakan Literasi Nasional. Jakarta: TIM GLN Kemdikbud.

Depdiknas. (2008). Panduan Pengembangan Bahan Ajar. Jakarta: Direktorat Jendral Manajemen Pendidikan Dasar dan 
Menengah.

Fitriani, W. (2019). Pengembangan Buku Cerita Bergambar Berbasis CorelDraw pada Mata Pelajaran SKI di Kelas III MI. Universitas Islam Negeri Raden Intan.

Gustanti, R. R. (2018). Pengembangan Buku Cerita Bergambar Tema 1 Subtema 1: Aku dan Diriku untuk Siswa Kelas I Sekolah Dasar. Universitas Sanata Dharma.

Kemendikbud RI. (2019). Perspektif baru dari hasil studi PISA 2018. www.youtube.com. https://youtu.be/q5fYlfRc8Zc

Khotimah, K. (2020). Pengembangan Media Cerita Bergambar Dwibahasa sebagai Sarana apresiasi Sastra Kelas IV Sekolah Dasar. Universitas Sultan Ageng Tirtayasa.

Kusumaningtyas, R. A., Damayanti, R., Fatmawati, B. S., \& Hastuti, S. B. (2018). Uji Kompetensi Guru: Pembahasan dan Praktek Soal. Bandung: Bumi Aksara.

Nuha, M. F., Pratiwi, Y., \& Nurchasanah, N. (2019). Buku Pengayaan Pembelajaran Cerita Fabel Berbasis Literasi untuk Siswa Sekolah Dasar, Jurnal Pengembangan, 5(2), 156-163. http://journal.um.ac.id/index.php/jptpp/ar ticle/view/11932

OECD. (2015). PISA 2015 Results in Focus. https://www.oecd.org/pisa/pisa-2015results-in-focus.pdf

OECD. (2019a). PISA 2018 Results. I. https://www.oecd.org/pisa/Combined_Ex ecutive_Summaries_PISA_2018.pdf

OECD. (2019b). Programme For International Student Assessment (Pisa) Results From PISA $2018.21-10$. https://www.oecd.org/pisa/publications/P ISA2018_CN_IDN.pdf

Purwanto, M. N. (2013). Prinsip-Prinsip dan
Teknik Evaluasi Pengajaran. Bandung: Remaja Rosdakarya.

Riduwan. (2013). Dasar-dasar Statistika. Jakarta: Alfabeta.

Rohman, S. (2017). Membangun Budaya Membaca Pada Anak Melalui Program Gerakan Literasi Sekolah. Jurnal Pendidikan Dan Pembelajaran Dasar, 4(1), 156-167.

Sribudi, S. (2018). Pengaruh Buku Cerita Bergambar terhadap Kemampuan Membaca Pemahaman Siswa Kelas III SDN 4 Sembalun Tahun Pelajaran 2018/2019. Jurnal Skripsi, 1-12.

Sugiyono. (2017). Metode Penelitian \& Pengembangan (Research and Development/R\&D). Jakarta: Alfabeta.

Suharto, P. P., \& Solihati, T. A. (2020). Analisis Kebutuhan Siswa Sd Terhadap Bahan Ajar Bahasa Inggris Berbasis Budaya Lokal Sunda. Metodik Didaktik: Jurnal Pendidikan Ke-SD-An, 15(2), 100-109.

https://doi.org/10.17509/md.v15i2.21679

Sundayana, R. (2014). Media dan Alat Peraga dalam Pembelajaran Matematika. Jakarta: Alfabeta.

Syahidi, M. (2020). Gotong Royong Meningkatkan Minat Baca di Banten.

Dinas Perpustakan Dan Kearsipan Provinsi Banten. https://dpk.bantenprov.go.id/Aktivitas/to $\mathrm{pic} / 152$

Uno, H. B., \& Lamatenggo, N. (2011). Teknologi Komunikasi \& Informasi pembelajaran. Bandung: Bumi Aksara.

Yuliana. (2018). Pengembangan Buku Cerita Bergambar sebagai Bahan Ajar dalam Perkembangan Moral Anak Usia Dini Taman Kanak-Kanak Islamiyah Desa Tanjung Raja. Universitas Islam Negeri Raden Intan. 